\title{
31. Contesting migration governance through legal mobilization
}

\author{
Leila Kawar
}

\section{INTRODUCTION}

How does the field of law matter in the governance and politics of migration? Over the past four decades, as immigration has emerged as one of the most pressing and polarizing areas of policymaking in both developed and developing economies, a large and growing sub-field of social science research has addressed human movement across borders and the political reactions such movements create. Yet on the question of who wields influence over immigration matters, the focus of attention tends to be directed to legislative politics and the exercise of executive discretion rather than to activity in court (but see discussion of liberal constraint thesis, Natter in this volume, Chapter 9).

When the juridical world does make an appearance in studies of immigration politics, it is discussed primarily in terms of judicial rulings that override policies enacted by the other branches. For example, studies of immigration politics acknowledge that massive immigration control sweeps, such as the US Government's "Operation Wetback" in the early 1950s, "would be illegal today, given court decisions that have enhanced the rights of immigrants" (Andreas 2004: 34). Similarly, the constitution of a European immigration policy domain beginning in the mid-1980s has been described as an effort by national immigration officials "to regain the discretion taken away by courts" (Guiraudon 2003: 264). As these two illustrations show, studies of immigration politics generally pay attention to legal interventions only in passing and only to the extent that judicial review places limits on the more important political action that takes place in other venues of policymaking.

Part of the reason for this is that judicial review is rarely actually exercised to overturn immigration policies enacted at the national level. Rights claims of individual foreign migrants, regardless of whether they are grounded in domestic or supra-national legal norms, tend to be "overshadowed" by a countervailing right of the sovereign nation to shut its borders (Dauvergne 2008: 27). While lower courts may be relatively less attuned to paradigms of sovereign authority and thus relatively more hospitable to immigrant claimants than courts at the pinnacle of the judicial hierarchy, the interventions of lower court judges in immigration cases are most often confined to an incremental "error-correcting function" that shies away from any direct challenge to policymaking (Law 2010: 174). Broadly speaking, empirical studies across national contexts indicate that immigration cases "have had generally conservative endings" (Legomsky 1987: 224), both in terms of their limited willingness to offer short-termremedies and in the sense that rules laid out in judicial opinions in immigration cases have rarely compelled other state officials explicitly to increase migrant admissions or to reduce migrant expulsions. Courts have been most assertive when applying sub-constitutional norms to immigration matters, but these interventions are rarely interventionist. 
While courts have indeed eschewed an interventionist stance on matters of national immigration policy, the argument in this chapter is that the traditional "impact" analysis of legal politics is too narrow. By narrowing their understanding of law to the rules in judicial opinions, and then assessing the degree to which these rules do or do not constrain the realization of restrictionist policy preferences, traditional studies of immigration policymaking have focused on only one dimension of legal politics. In focusing on the coercive power of courts, they have failed to consider how the process of engaging with law and courts may construct migration governance in politically important ways.

The constructivist socio-legal approach outlined here builds on a body of law and society scholarship emphasizing that law is not only a set of rules and remedies but also a field of cultural practice. Conceptualizing legal activity as a cultural practice highlights the symbolic power of court-centred contestation to reconfigure how migration politics is expressed and understood. It takes as its starting point the observation that practical engagements with legal forms and conventions construct webs of symbolic relations that have "radiating" and "centrifugal" effects that are more catalytic than coercive in nature (Galanter 1983). By shifting the focus away from the official rules laid out in immigration cases and towards the process of legal mobilization and its attendant assemblages of informal meaning-making, this postpositivist understanding of law allows us to explore how legal engagements generate new forms of action as well as new ideas about migrants and migration. The repercussionsof engaging with these varying legal structures and conceptual assemblages may extend far beyond any single case's short-term remedy or doctrinal contribution.

In exploring how this constructivist socio-legal approach contributes to our understanding of the governance and politics of migration, the chapter analyses not only the social frames and narratives assembled through legal processes but also the political stakes of these assemblages. As the discussion below makes clear, law is not an alternative to politics but rather a deeply political terrain with the capacity to produce, reproduce and transform understandings of actors and relationships implicated by migration control policies. Drawing on recent socio-legal scholarship, the chapter elucidates these political dynamics by offering an overview of the context and conditions of contemporary immigration-centred legal mobilizations (Section II), the process by which these legal claims are framed (Section III), and the political stakes of this juridification of migration politics (Section IV). Attending to legal mobilization's role in constructing migration governance and politics is both relevant and timely for advancing a critical research programme. The approach set forth here offers tools for scholars espousing various research methodologies and investigating a range of diverse contexts, who wish to develop a richer understanding of the dynamics of court-based contestations of migration policy.

\section{CONTEXT AND CONDITIONS OF LEGAL MOBILIZATION}

In both Europe and North America, the 1973 oil shocks ushered in the contemporary period of immigration politics characterized by restrictive immigration policies. Across industrialized states, irregular migrants and guest workers were seen as a kind of "economic shock absorber"; they had been brought into the labour market under different economic conditions and they could be sent home when their labour was no longer needed. In Europe, the response to economic recession was particularly dramatic: governments abruptly suspended all foreign-worker recruitment and took steps to encourage foreigners to return home. Restrictionism was also 


\section{Handbook on the governance and politics of migration}

a feature of policy responses to the economic downturn in other migrant-destination states. This broad shift towards restrictionism thus offers a backdrop against which to understand contemporary legal mobilization and legal activism on immigration issues.

Yet if the restrictionist turn in policymaking set the stage for legal responses, immigrationcentred political lawyering was also inspired by and incorporated into contem- poraneous social movements whose goals extended beyond the immigration domain. The emergence of immigration-centred legal mobilization is part of the transnational history of theNew Left. Many of the lawyers drawn to contest immigration policies in court beginning in the 1970s were part of a cohort of recent law school graduates who, although they did not them- selves identify as first- or second-generation immigrants, brought their experiences in student protest movements into their professional careers. In both the USA and elsewhere, this cohortof law graduates became enthusiastic participants in the mobilizations of immigrant groups against restrictive immigration policies, and at the same time viewed immigration-centred legal work as an area on which they could leave their mark professionally (Kawar 2015: 33-44). In some instances, recent graduates took inspiration from counterculture critiques developed by the student movement's intellectual supporters as they experimented with nascent forms of "cause lawyering" (Israel 2003). In other instances, the New Left's student protest agenda converged with immigration policy issues, as with efforts by some members ofthe American immigration bar to defend Iranian student activists protesting US foreign policyin the 1970s (Schacher 2016). The emergence of immigration-centred legal mobilizations in the USA during the 1970s has also been associated with the somewhat distinct histories of civilrights protest movements (Buff 2018; Chavez 2002; Gutiérrez 1995), civil rights lawyering (Olivas 2005), and "public interest law" (Cummings 2007).

Importantly, the breakthrough of human rights politics also provided resources and opportunities for the emergence of legal mobilizations targeting immigration policies. We see an early example of this confluence of immigration issues with human rights in the American legal movement for Haitian rights that began in the 1970s, which was significant for its capacity to leverage the resources of both developing human rights advocacy institutions and those associated with civil rights and New Left lawyering (Kahn 2013; see also Hamlin and Wolgin 2012). Since the mid-1990s, this nexus of human rights politics with legal mobilizations targeting immigration policies has substantially deepened. The so-called European "rights revolution", propelled by EU integration and broader European-level developments, has provided a favourable context for court-centred contestation of immigration policies, which can be understood as a subset of the broader development of legal mobilization on behalf of minorities and vulnerable/marginalized groups in Europe's multi-level legal-judicial system (Anagnostou 2014; more generally on the "liberal constraint" of European immigration policymakers through constitutionalism, see Natter in this volume, Chapter 9). Legal activists in a number of European countries have sought to mobilize human rights provisions in European treaties, such as those prohibiting torture, as an avenue for expanding the rights of asylum seekers and other migrants (Conant 2016; Kubal 2017; Psychogiopoulou 2014).

Looking more broadly, we see that the growth of transnational human rights cause lawyering has offered both inspiration and resources for legal mobilizations targeting restrictive immigration policies in a number of settings in the global South. In Latin America, legal mobilization efforts have taken inspiration not only from the expansive migrant rights jurisprudence of the Inter-American human rights system but also from recent efforts to constitutionalize international human rights treaties (Dembour 2015; Meili 2017). In the case of South Africa, 
litigation efforts on behalf of migrants and refugees have their roots in public interest law organizations forged during the country's anti-apartheid struggle and continue to develop linkages with transnational human rights and refugee rights institutions (Handmaker 2011). What this brief overview of past and present immigrant rights mobilizations across national contexts clearly demonstrates is that the contemporary era of regulated national borders and restrictive migration governance has also simultaneously created space for a wide range of court-centred contestations of such policies.

\section{THE FRAMING OF LEGAL CLAIMS}

In order to grasp the dynamics of legal mobilization, it is important to attend to the process by which these various efforts to mobilize courts have translated political goals into legal claims. Mobilizations taking place in and around courts can be distinguished from other political strategies, such as lobbying or protest, through their relatively greater reliance on law as a mode of enunciation. Certainly, individual non-citizens routinely draw on a mix of formal and informal norms when navigating their encounters with judges and other state officials, as ethnographic studies have emphasized (for a summary, see Vetters et al. 2017: 26-7). Yet it is important to emphasize that professionally trained jurists are uniquely competent to identify and utilize margins of interpretation within the law to advance political goals. This process of knowledge production includes not only identifying legal issues but also constructing complex events and relationships as "facts" that can be presented to courts to support a claim.

One way of mobilizing the categories of formal law to advance political goals is to present claims based within the normative corpus of immigration law itself. Marshalling evidence and formulating arguments about the meaning of immigration law's normative categories is the stock-and-trade of the immigration bar. Qualitative research on legal mobilization efforts in Germany suggests that this type of claims-making, operating within the normative bounds of existing immigration law tends to be client-centred and tactically pragmatic rather than conflict-oriented (Hahn 2018). At the same time, a number of large-scale empirical studies have shown that representation by counsel is associated with dramatically more favourable outcomes for migrants (for a summary, see Eagly and Shafer 2015), suggesting that providing low- or no-cost legal representation promotes wider "access to justice" in migration governance. The non-negligible importance of such representation is made all-the-more appreciable by studies of political regimes which curtail migrant advocates' access to the courts (Kemp and Kfir 2016). Its political valence might thus be read as effecting a marginal shift in power relations in favour of migrants even in the absence of any broader protest movement.

Mobilization of immigration law is likely to effect more enduring structural change when it is organized on behalf of specific migrant communities. Often referred to as "movement lawyering" or "community lawyering", this type of legal mobilization can provide an important resource for migrant protest movements that have developed their own political goals and strategies of protest. The bulk of such lawyering typically involves either advising on the immigration consequences of particular protest tactics or individual servicing of community members so as to identify possible avenues of relief. Legal practice may also involve mobilizing in court to defend movement participants targeted on account of their immigration status. The framing of legal claims in these contexts, while remaining within the normative framework of immigration law, nevertheless creates space for political mobilization without 


\section{Handbook on the governance and politics of migration}

fundamentally altering movement goals (Ashar 2017). For instance, lawyering of this type has a long tradition of defending movement leaders against deportation proceedings aiming to undermine their ability to undertake activist campaigns.

When the aim is to effect immigration policy change more directly through litigation, then research suggests that legal mobilization will gravitate towards framing legal claims regarding the illegality of the immigration regime itself (but see the counter-tendency of "crimmigration' discussed by Moffette in this volume, Chapter 28). This can be achieved by invoking higher-order norms, often drawn from constitutions or international treaties, so as to open new passageways of law. Social researchers have used the terms "impact litigation" or "legal activism" to distinguish this policy-oriented litigation (for a discussion of terminology, see Kawar 2015: 19-21). The concept of "lawfare" has also been used to describe efforts to "reorganize the cartography" of immigration law through intensive and persistent litigation (Kahn 2017). This invocation of higher-order norms is symbolically potent to the extent that it evokes foundational narratives of the political community. For instance, in calling upon the Warren Court's equal protection jurisprudence when formulating claims on behalf of undocumented migrants and asylum seekers, American legal activists reframed their clients as members of a racial minority with a history of state-sanctioned discrimination justifying assertive judicial review. By contrast, immigration-centred legal activism in France has downplayed minority rights and has instead invoked norms against autocracy and administrative rule by fiat that have a particular potency in the French national experience (Kawar 2012). In both instances, the construction of "facts" and framing of legal claims was organized strategically with the aim of persuading courts to extend existing rights-based or authority-limiting higher-order norms into the domain of immigration policymaking, in effect using appellate litigation to create new law case-by-case.

Impact litigation is a highly specialized form of mobilizing courts against restrictive immigration policies, and its practice may become further specialized as individual jurists or legal organizations develop targeted expertise in a particular subset of legal questions. This trend towards specialization is propelled in part by liberal elite supporters seeking to "rationalize" the activities of their funding recipients so as to avoid duplication of effort. For instance, in the USA, the Ford Foundation played a dominant role during the 1980s in structuring various specialties of immigration-centred impact litigation, with some groups tasked with constitutional due process issues while others were told to focus on refugee issues or the nexus of immigration and criminal law (Kawar 2011; cf. Moffette in this volume, Chapter 28). Moreover, while many practitioners are drawn towards the law-centred strategies of impact litigation, liberal elites have shown a tendency to support individuals and groups who are already endowed with qualities and dispositions that they value. Along these lines, one comparative study of post9/11 immigrant defenders in the USA and UK identifies a correspondence between the level of "legal capital" held by professionally socialized jurists and the degree to which these attorneys were encouraged to pursue a policy-centred form of practice (Prabhat 2016: 61-76). As such studies demonstrate, different forms of migrant-centred legal mobilization vary substantially in how they engage with the legal field. 


\section{THE POLITICAL STAKES OF JURIDIFYING MIGRATION POLITICS}

How successful have these efforts at mobilizing law and courts been in curtailing the scope of restrictionist immigration policies? As discussed in the introduction to this chapter, traditional "impact studies" have addressed this question in terms of the capacity of the rules or outcomes of judicial decisions to coercively overturn existing policies and prevent their legislative reenactment. Viewed through this metric, legal mobilization in the immigration domain has had a relatively minimal impact. Without disagreeing with this proposition about the constrained nature of judicial review in immigration matters, the discussion in this chapter has suggested that a post-positivist legal analysis, that is, moving beyond a rule-based and top-down conception of law to focus on its discursive and performative dimensions, is helpful in turning our attention towards the broad range of legal mobilization's potential radiating effects in the domain of migration governance and on relations of power more generally.

We see one type of potential radiating effect in the association between immigration-centred legal mobilization and an enhanced visibility of the judiciary in immigration politics. National judges may be empowered by high-profile litigation contesting immigration policies on the basis of constitutional or international human rights, taking these cases as an invitation to enhance their position against other national or supra-national jurisdictions or against an autocratic president (on the human rights discourse in migration governance see Hart in this volume, Chapter 8). The judiciary's greater visibility may shift the tenor and/or content of immigration policymaking, especially if administrators who previously had a relatively free hand in immigration matters must now formulate their policies more dialogically (Kawar 2014). In partial or transitioning democracies, legal mobilization on immigration issues can be part of a broader dynamic of constitutionalizing international human rights obligations (Meili 2017).

This increased visibility of the judiciary has not gone unnoticed by immigration policy officials. Responding to the increased volume of appeals of agency decisions as well as to specific high-profile legal activist campaigns, national policymakers in a number of countries have sought to prevent certain types of immigration cases from gaining a judicial hearing. In the USA, legislative jurisdiction-stripping in the mid-1990s can be understood as a particularly visible manifestation of a spiralling adversarial dynamic in which routinized class action litigation played a prominent role (Kawar 2015: 103-26). During the same period, German politicians with an anti-immigrant agenda succeeded in granting administrative court judges more control over their asylum dockets in the hope of accelerating the removal of claimants and deterring future arrivals (Soennecken 2016).

Some scholars have described these developments in terms of a conservative backlash operating against a steadily increasing number of precedent decisions interpreting international human rights norms in ways that are favourable to individual asylum seekers (Cummings 2007; Hamlin 2015). Considering the broader context, however, it becomes clear that many seemingly favourable precedents must be reassessed against a contemporaneous reshaping of jurisdiction to strip migrants of rights, which in a number of instances has been legitimized by appellate courts. Indeed, the recent transnational diffusion of a model of offshore interdiction and detention of asylum seekers, rather that harkening the victory of human rights, has been interpreted as signalling a return to immigration doctrines historically associated with judicial deference to territorial expansion and racially stratified imperial regimes (Kahn 2013: 
249-76; on wider debates of ethno-cultural and postcolonial statehood, see El Qadim, Chapter 19; Mayblin, Chapter 2; Moulin and Rodrigues, Chapter 3, all in this volume). Regardless of whether the recent revival of such doctrines proves enduring, it reminds us that judges may exercise their power over migration governance while abdicating any responsibility for reviewing human rights or humanitarian claims. In short, critically minded scholars should avoid assuming that an increased visibility for the judiciary as an institutionalized player in immigration matters will inevitably produce results favourable for migrants.

If impact litigation has not always produced the outcomes that immigrant rights legal activists have sought, this does not mean that the broader phenomenon of framing migrants' claims in terms of formal law cannot have important radiating effects on groups and individuals mobilizing for social change. We might speak of legal mobilization operating in a "narrow but significant space" of possibilities; narrow because it is heavily framed by state interests but also significant in terms the capacity to catalyse or facilitate policy change at the highest levels (Handmaker 2011: 81). To the extent that legal mobilization is associated with sustained mobilization, contestation, and protest by migrants and their supporters, it can operate to politicize migration governance. This association can take many forms: catalysing a coalition, crystallizing agendas, contributing resources for ongoing mobilization, reinforcing and encouraging movement participants, offering opportunities for exercising agency, calling into question existing ways of understanding the issues, etc. As anthropologist Susan Coutin insightfully points out, it is impossible to talk about "impact" on a movement because migrants and their advocates construct legal and political claims on the artefacts left by prior rounds of contestation (Coutin 2011).

While there is nothing inherently empowering or disempowering about turning to law, some instances of legal mobilization may empower lawyers more than they empower excluded groups and communities. Some scholars, influenced by a more general critical legal studies analysis of public interest lawyering, have attempted to develop analytical rubrics capable of distinguishing forms of legal mobilization that tend to empower movements for social change, on the one hand, from impact litigation strategies, on the other hand, that tend to depoliticize or disempower (Ashar 2017). While it is important to continuously reflect on lessons learned from past experiences, scholars and practitioners must also remain cognizant of the context-dependent and thus shifting nature of power and resistance. Along these lines, Jamie Longazel's in-depth case study of mobilization and backlash in one American town illustrates the complexity of these dynamics, showing how the lawsuit that overturned a restrictionist local statute in Hazelton, Pennsylvania was interpreted by some local politicians as an instance of "powerful litigators" and "activist judges" undermining their "innocent small town" (Longazel 2016: 10). In this case, it was the challenge to the law which reinforced an existing narrative of local Latino threat, with the result that an increasing number or locals participated in backlash mobilization. At the same time, the lawsuit allowed local Latina/o residents to see their plight through a new, legalistic lens. A high-profile lawsuit that inspired backlash thus also offered less powerful local groups "a stronger, more culturally resonant vision" of the legislation at issue "as impinging on immigrants' rights" (Longazel 2016: 52).

This points to a broader insight, which is that it is not simply the rules enunciated in a judicial decision that propel mobilization and counter-mobilization, but also how the various knowledge-assemblages forged through court-centred contestation are appropriated and reassembled by participants in both local and national-level politics. Three examples illustrate the diversity of ways in which frames, narratives and performances constructed through activity in 
court can take on a life of their own in national immigration politics. The first example comes from the USA, where high-visibility courtroom proceedings in the early 1980s enhanced the prestige of immigrant rights legal activists and allowed them to claim a seat at the table when the US Congress turned to comprehensive immigration policy reform in the mid-1980s. In this case, apart from any specific ruling, the size of the class action lawsuit generated attention for asylum issues and galvanized the legal profession to become more involved in immigration politics (Kawar 2015: 71-6). A second example comes from France, where the 1978 Conseil d'états decision quashing a decree restricting family migration, while never binding in any technical sense on national legislators, nevertheless offered rhetorical building blocks for a narrative developed by legal activists that associated the sitting government and its ministers with autocratic rule. This narrative proved particularly potent, particularly when taken up by members of the opposition party and had the effect of tainting the legitimacy of the government's ongoing immigration policy initiatives (Kawar 2015: 59-64). A third example comes from the Federal Republic of Germany, where judicial decisions on family migration in the mid-1970s inspired increasingly vocal opposition to these policies among some members of the government and progressive civil society groups, who liberally interpreted the decisions and appealed to rights never recognized by the courts. Courts thus supplied the "raw materials" from which proponents of more generous family reunification policies built a rights-based framing of the issues that was powerful enough to block a number of proposed restrictive reforms (Bonjour 2016: 341).

Importantly, in all three of the examples discussed above, courts generally shied away from issuing wide doctrinal pathways by which immigration policy would be subordinated to higher-order norms. As we saw, however, even when they are doctrinally curtailed, court decisions may nevertheless provide textual support for migrant rights narratives in the broader politics of migration policymaking. Or they may be curtailed through policymakers' creative exclusionary responses (see, for example, Kramer et al. 2018). The important point to take away is that the precise nature of these radiating effects and the conditions under which they will be produced cannot be known in advance and must be discerned through careful analysis that attends to the specificities of how, when, where, and why legal mobilization takes place.

\section{CONCLUSION}

This discussion of legal mobilization has focused on how migration governance both shapes and is shaped by judicially supervised contestations of immigration law. As we saw, many of the contemporary organizational structures associated with this field of practice arose in response to a global turn to restrictive immigration policies that began in the 1970s. At the same time, this discussion emphasized links between the emergence of immigration-centred legal mobilizations and the broader context of rights-based political mobilizations, evidenced both in the new social movements of the 1970s and in contemporary international human rights activism. In addition, the theory of legal mobilization advanced here embraces a constructivist approach that conceptualizes activity in court as potentially symbolically potent apart from any rules or outcomes produced in judicial decisions. Seen in this light, both migrants and their lawyers are constructed through legal mobilization strategies that focus variously on margins of interpretation within immigration law or on higher-order norms of rights or legal- ity. Seemingly technical procedures for framing legal claims and representing "facts" may also 


\section{Handbook on the governance and politics of migration}

have radiating effects in the spheres of legislative and administrative policymaking, many of which cannot be known in advance and must be studied afresh in each context in which legal mobilization takes place.

In the guise of a conclusion, it may be helpful to mention three sets of questions that were largely left unaddressed in the foregoing discussion and which may thus be read as suggestions for future trajectories of research. First, it is important to note that the mobilization of legal discourses is not limited to formal state forums. Individuals and groups routinely mobilize legal strategies for negotiating exchanges and resolving disputes in many social settings without relying on direct official intervention. An important subset of the socio-legal literature on law and social movements advances a theory of legal mobilization whose "trademark" contribution involves shifting analytical focus toward such everyday struggle (McCann 1994: 8). Initiatives of individual citizens and non-citizens to mobilize discourses of rights or other legal ideologies as part of a strategy of protest outside of judicially supervised legal conflict situations are less easily distinguished from the broader phenomenon of political mobilization (see Ataç and Schwenken in this volume, Chapter 30), but this certainly does not imply that they are less important for analysis of the dynamics of migration governance.

Nor has the preceding discussion considered in detail the efforts of jurists to mobilize politically through strategies such as lobbying or organizing that operate outside of judicially supervised legal conflict situations. The level and quality of these political lawyering strategies, sometimes aiming to defend rule of law values in the abstract, may have important consequences for migration governance, particularly when immigration law becomes an avenue for addressing so-called national security emergencies (Prabhat 2016). Moreover, leftist legal networks have a long history of political mobilization to defend labour movement leaders as well as rank-and-file union members from waves of "deportation terror", such as those immediately after the First World War and during the 1930s and early 1950s. Recent historical scholarship, while not focused specifically on the politics of legal mobilization, has sought to excavate the history of this era of Popular Front legal and political advocacy on behalf of the foreign born (Buff 2018; Gutiérrez 1995).

Finally, this discussion has centred on legal mobilization efforts that contest the scope and application of immigration law (including related legal regimes - such as refugee law - that offer affirmative avenues for non-citizens to acquire legal immigration status). Placing the focus on immigration law replicates a conceptual divide within formal law, one that separates the normative regime dedicated to control of migration (through conditions for admission and stay) from the broader body of laws that govern the welfare of migrants. Yet these two regimes are less easily separated on the ground: empirical research shows that individual worker legal mobilization is considerably dampened by a context of heightened local immigration control (Gleeson 2015), while at the level of policymaking there appears to be a close empirical relationship between social policy and the conditions placed on foreigners' admission and stay (Blauberger et al. 2018). Analysis of the recent trend to subordinate labour and employment rights to immigration status further confirms that the hierarchical relationship that law asserts between these related normative regimes is in fact inherently political and thus something that can and should be contested through political and legal mobilizations (Fudge and Herzfeld Olsson 2014). Indeed, court-based contestation of migrant labour rights comprises one of several mobilization strategies recently deployed by an emergent alt-labour movement (cf. Piper in this volume, Chapter 32) that some see as pointing the way for a rejuvenated labour movement more generally (Dias-Abey 2018). For these reasons, critical analysis of migration 
governance should attend to the politics of these forms of legal mobilization and should investigate their relationship to the forms of court-based contestation of immigration policy on which this discussion has primarily focused.

\section{REFERENCES}

Anagnostou, D. (2014), 'Law and Rights' Claiming on behalf of Minorities in the Multi-level European System', in Dia Anagnostou (ed.), Rights and Courts in Pursuit of Social Change: Legal Mobilisation in the Multi-Level European System, London: Bloomsbury, pp. 1-24.

Andreas, P. (2004), Border Games: Policing the United States/Mexico Divide, Ithaca, NY: Cornell University Press.

Ashar, S.M. (2017), 'Movement Lawyers in the Fight for Immigrant Rights', U.C.L.A. Law Review, 64, 1464-1507.

Blauberger, M., A. Heindlmaier, D. Kramer, D. Sindbjerg Martinsen, J. Sampson Thierry, A. Schenk and B. Werner (2018), 'ECJ Judges Read the Morning Papers. Explaining the Turnaround of European

Citizenship Jurisprudence', Journal of European Public Policy, DOI: 10.1080/13501763.2018.1488880.

Bonjour, S. (2016), 'Speaking of Rights: The Influence of Law and Courts on the Making of Family Migration Policies in Germany', Law \& Policy, 38 (4), 328-48.

Buff, R.I. (2018), Against the Deportation Terror: Organizing for Immigrant Rights in the Twentieth Century, Philadelphia, PA: Temple University Press.

Chavez, E. (2002), "Mi Raza Primero!”: Nationalism, Identity, and Insurgency in the Chicano Movement in Los Angeles, 1966-1978, Berkeley: University of California Press.

Conant, L. (2016), 'Who Files Suit? Legal Mobilization and Torture Violations in Europe', Law \& Policy, 38 (4), 280-303.

Coutin, S. (2011), 'Falling Outside: Excavating the History of Central American Asylum Seekers', Law and Social Inquiry, 36, 569-92.

Cummings, S.L. (2007), 'The Internationalization of Public Interest Law', Duke Law Journal, 57, 891-959.

Dauvergne, C. (2008), Making People Illegal: What Globalization Means for Migration and Law, New York: Cambridge University Press.

Dembour, M.-B. (2015), When Humans Become Migrants, Oxford: Oxford University Press.

Dias-Abey, M. (2018), 'Justice on Our Fields: Can "Alt-Labor" Organizations Improve Migrant Farm Workers' Conditions?' Harvard Civil Rights/Civil Liberties Law Review, 53, 167-211.

Eagly, I.V. and S. Shafer (2015), 'A National Study of Access to Counsel in Immigration Court', University of Pennsylvania Law Review, 164 (1), 1-91.

Fudge, J. and P. Herzfeld Olsson (2014), 'The EU Seasonal Workers Directive: When Immigration Control Meets Labour Rights', European Journal of Migration and Law, 16, 439-66.

Galanter, M. (1983), 'The Radiating Effects of Courts', in Keith D. Boyum and Lynn M. Mather (eds), Empirical Theories of Courts, New York: Longman, pp. 121-46.

Gleeson, S. (2015), 'Brokering Immigrant Worker Rights: An Examination of Local Immigration Control, Administrative Capacity and Civil Society', Journal of Ethnic and Migration Studies, 41 (3), 470-92.

Guiraudon, V. (2003), 'The Constitution of a European Immigration Policy Domain: A Political Sociology Approach', Journal of European Public Policy, 10 (2), 263-82.

Gutiérrez, D.G. (1995), Walls and Mirrors: Mexican Americans, Mexican Immigrants, and the Politics of Ethnicity, Berkeley: University of California Press.

Hahn, L. (2018), 'Strategically Mobilizing (against) Migration Law', paper presented at the Workshop on Precarious States, London School of Economics, 31 May.

Hamlin, R. (2015), 'Ideology, International Law, and the INS: The Development of American Asylum Politics 1948-Present', Polity, 47 (3), 320-36.

Hamlin, R. and P.E. Wolgin (2012), 'Symbolic Politics and Policy Feedback: The United Nations Protocol Relating to the Status of Refugees and American Refugee Policy in the Cold War', International Migration Review, 46 (3), 586-624. 


\section{Handbook on the governance and politics of migration}

Handmaker, J. (2011), 'Public Interest Litigation for Refugees in South Africa and the Potential for Structural Change', South African Journal on Human Rights, 27, 65-81.

Israel, L. (2003), 'Faire émerger le droit des étrangers en le contestant, ou l'histoire paradoxale des premières années du GISTI', Politix, 16 (62), 115-44.

Kahn, J.S. (2013), 'Islands of Sovereignty: Haitian Migration and the Borders of Empire', PhD dissertation, University of Chicago.

Kahn, J.S. (2017), 'Geographies of Discretion and the Jurisdictional Imagination', PoLAR: Political and Legal Anthropology Review, 40 (1), 5-27.

Kawar, L. (2011), 'Legal Mobilization on the Terrain of the State: Immigrant Rights Practice in Two National Legal Fields', Law and Social Inquiry, 36 (2), 354-87.

Kawar, L. (2012), 'Juridical Framings of Immigrants Rights in the United States and France: Courts, Social Movements, and Symbolic Politics', International Migration Review, 46 (2), 414-55.

Kawar, L. (2014), 'Commanding Legality: The Juridification of Immigration Policy Making in France', Journal of Law and Courts, 2 (1), 93-116.

Kawar, L. (2015), Contesting Immigration Policy in Court: Legal Activism and Its Radiating Effects in the United States and France, New York: Cambridge University Press.

Kemp, A. and Kfir, N. (2016), 'Mobilizing Migrant Workers' Rights in "Non-immigration" Countries: The Politics of Resonance and Migrants' Rights Activism in Israel and Singapore', Law \& Society Review, 50 (1), 82-116.

Kramer, D., J. Sampson Thierry and F. Van Hooren (2018), 'Responding to Free Movement: Quarantining Mobile Union Citizens in European Welfare States', Journal of European Public Policy, DOI: $10.1080 / 13501763.2018 .1488882$.

Kubal, A. (2017), 'In Search of Justice: Migrants' Experiences of Appeal in the Moscow City Court', in M. Kurkchiyan and A. Kubal (eds), Sociology of Justice in Russia, Cambridge: Cambridge University Press, pp. 92-117.

Law, A.O. (2010), The Immigration Battle in American Courts, New York: Cambridge University Press.

Legomsky, S.H. (1987), Immigration and the Judiciary: Law and Politics in Britain and America, New York: Oxford University Press.

Longazel, J. (2016), Undocumented Fears: Immigration and the Politics of Divide and Conquer in Hazelton, Pennsylvania, Philadelphia, PA: Temple University Press.

McCann, M.W. (1994), Rights At Work: Pay Equity Reform and the Politics of Legal Mobilization, Chicago, IL: University of Chicago Press.

Meili, S. (2017), 'The Human Rights of Non-Citizens: Constitutionalized Treaty Law in Ecuador', Georgetown Immigration Law Journal, 31, 347-87.

Olivas, M.A. (2005), 'Plyler v. Doe, the Education of Undocumented Children, and the Polity', in Peter H. Schuck and David A. Martin (eds), Immigration Stories, New York: Foundation Press, pp. $197-220$.

Prabhat, D. (2016), Unleashing the Force of Law, London: Palgrave Macmillan.

Psychogiopoulou, E. (2014), 'European Courts and the Rights of Migrants and Asylum Seekers in Greece', in D. Anagnostou (ed.), Rights and Courts in Pursuit of Social Change: Legal Mobilisation in the Multi-Level European System, London: Bloomsbury, pp. 129-53.

Schacher, Y. (2016), 'Exceptions to Exclusion: A Prehistory of Asylum in the United States, 1880-1980', $\mathrm{PhD}$ dissertation, Harvard University.

Soennecken, D. (2016), 'The Paradox of Docket Control: Empowering Judges, Frustrating Refugees', Law \& Policy, 38 (4), 304-27.

Vetters, L., J. Eggers and L. Hahn (2017), 'Migration and the Transformation of German Administrative Law: An Interdisciplinary Research Agenda', Max Planck Institute for Social Anthropology Working Papers, Halle, Germany: Max Planck Institute for Social Anthropology. 